\title{
ENTFERNUNG/REINIGUNG/ENTJUDUNG: DŮSLEDKY NACISTICKÉ RASOVÉ PERZEKUCE PRO PROFESORSKÝ SBOR LÉKAŘSKÉ FAKULTY NĚMECKÉ UNIVERZITY V PRAZE, 1938-1945*
}

\author{
MICHAL V. ŠIMU゚NEK
}

\section{ENTFERNUNG/REINIGUNG/ENTJUDUNG: THE IMPACT OF NAZI RACIAL PERSECUTION ON THE PROFESSORIAL STAFF OF THE FACULTY OF MEDICINE OF THE GERMAN UNIVERSITY IN PRAGUE, 1938-1945}

\begin{abstract}
One of the consequences of the Nazi occupation of the Czech Lands in 1939-1945 was that the careers of many scientists and academics either experienced politically and ideologically driven changes or were forcibly ended. Emigration, racial persecution, or involvement in the resistance movement had a fatal impact on the previously multicultural and multilingual scientific community in the Czech Lands. This had a significant effect also on the medical profession. Using the example of some of its elite representatives, namely university teachers (professors and senior lecturers), one can trace the development of an important part of traditional, linguistically German science and education in the Czech Lands. This study contributes to research focused on description and analysis of changes in the scientific and personnel basis of medical science in the Czech Lands during the period in question. It also adds to our knowledge of development of sciences and scientific institutions, in particular at the Faculty of Medicine of the German University in Prague. This contribution is based on the study of materials kept in both domestic and foreign archives.
\end{abstract}

Keywords: Nazism - Antisemitism - Universities - Medicine - WW2

DOI: $10.14712 / 23365730.2018 .23$

Dne 10. května 1933 hořely v německých univerzitních městech ohně, nenávratně stravující knihy „nežádoucích“, především židovských autorů. V Berlíně při této příležitosti Joseph Goebbels (1897-1945) před mnohatisícovým davem halasně deklamoval, že ,dobu upadajícího židovského ducha máme za sebou a [nacionálněsocialistická - pozn. aut.] revoluce uvolnila cestu duchu německému“. ${ }^{1}$ „Rasová“" podmíněnost vědeckých výkonů, internacionalita a neslučitelnost s ,germánskou vědou“ - to byla hlavní klišé nacistických ideologů a propagandistů. ${ }^{2}$ Př́nos židovské vzdělanosti byl přitom vybranými autory systematicky popírán, což měly mimo jiné dokazovat i dějiny vědy. Nacistická propaganda dlouhodobě

* Tato studie vznikla v rámci projektu GA ČR 17-27132S.

1 Srov. Zprávy z Německa - Pálení knih, Židovské zprávy 16/20, 1933, s. 1; Časopis československých knihovníků 13/1-2, 1934, s. 2.

2 Alfred Rosenberg, Mythos des 20. Jahrhunderts. Eine Wertung der seelisch-geistigen Gestaltenkämpfe unserer Zeit, München 1938, s. 121. Dále např. Erhard Lehmann, Der Einfluß des Judentums auf das französische 
pracovala s nesmiřitelným antagonismem ,židovské“ či ,,požidovštělé vědy“ (jüdische/verjudete Wissenschaft) a „německé vědy“, která měla spočívat na völkisch základech. Proto se lze setkat např́klad s ,německou fyzikou“ (deutsche Physik) či „německou biologií “ (deutsche Biologie), kterou její proponenti velmi křečovitě a exaltovaně vyhlašovali, jako v př́padě nositele Nobelovy ceny za fyziku z roku 1919 Johannese Starka (1874-1957). Tak např́klad bratislavský rodák Philipp Lenard (1862-1947), rovněž nositel Nobelovy ceny za fyziku z roku 1905 a promotor ,německé fyziky“, který publikoval již roku 1929 jednu z prvních populárních biografických prací pro dějiny přírodních věd, neměl pro její roli v dějinách jiného hodnocení, než že se jednalo o „myšlení jiného druhu“, které „,se nikdy nehodilo k ničemu jinému nežli k okamžitým paúspěchům anebo k omračování, nebo $v$ nejlepším př́padě $k$ dokončeni toho, co už v podstatě bylo započato".3 Mezi třiašedesáti osobnostmi, které měly podle něj do roku 1918 zásadně ovlivnit přírodní vědy, pak konsekventně nezahrnul nikoho, kdo by spadal právě do „myšlení jiného druhu“. Dokazování „německosti“ jednotlivých vědeckých oborů se tak stalo symptomem tohoto období ve vývoji dějin věd ve střední Evropě. Oficiální Damnatio memoriae roku 1940 stvrdilo i říšské ministerstvo vědy a vzdělání lidu (Reichsministerium für Wissenschaft, Erziehung und Volksbildung), když ve svém úředním listě přikazovalo, aby v seznamech literatury vědeckých a dizertačních prací nebyli uváděni židovští autoři, respektive byli uváděni alespoň odděleně od autorů ,árijských“. 4

Obě tyto události - veřejné pálení knih a snaha vymazat z nich jména nežádoucích autorů - příznačně ohraničují radikální proměnu vztahu k moderní vzdělanosti liberální éry, k níž došlo ve jménu nacistické ideologie, a zásah do akademických svobod a svobody vědeckého bádání. Ačkoli soupisy exponovaných osobností židovského původu, zpravidla zahrnující i oblast středního a vysokého školství, kolovaly v Německu již od konce dvacátých a počátku třicátých let 20. století, teprve uchopení moci nacisty znamenalo zásadní změnu. ${ }^{5}$ Cílem personální politiky se totiž stalo nejen záměrné rozbití tradičních vazeb ve vědecké a vysokoškolské oblasti, nýbrž i přeměna celého univerzitního a vědecko-výzkumného sektoru pomocí bezprecedentních a drastických zásahů. Vedle prvotních aktivit zdola, které byly v Německu po uchopení moci nacisty zpravidla v režii studentských organizací, bylo pro tyto zásahy záhy využito především legislativně-byrokratických opatření prosazovaných shora, v rámci tzv. správně formálního jednání (verwaltungsförmiges Verfahren). ${ }^{6}$ Klíčovým bylo přijetí zákona o znovuobnovení služebního úřednictva

Denken der Gegenwart (= Schriften des Deutschen Instituts für Aussenpolitische Forschung, H. 65/ Frankreich gegen die Zivilisation, H. 10), Berlin 1940, s. 34.

3 Philipp Lenard, Velci př́rodozpytci. Dějiny přirodovědného bádání, Praha 1943, s. 11.

4 Bundesarchiv (BArch) Berlin, f. R58/150, Meldungen aus dem Reich, 10. 4. 1940, s. 8 (,Zitieren jüdischer Autoren bei Dissertationen").

5 Der jüdische Einfluß an den Deutschen Hohen Schulen. Ein familienkundlicher Nachweis über die jüdischen und verjudeten Universitäts- und Hochschulprofessoren, Teile 1-8, Göttingen 1928-1932; Karl HoppmanN, Über den Stand der Verjudung der akademischen Berufe, Berlin 1931. Tento spisek překvapivě neuvádí přehledy pro Prahu či Brno, nýbrž podíl židovských lékařů ve vybraných pohraničních (,sudetských“) městech (Těšíně, Opavě) či učitele na středních školách v těchto oblastech. Obecně k těmto seznamủm srov. Peter Th. Walther, Entlassungen und Exodus. Personalpolitik an der Medizinischen Fakultät und in der Charité 1933, in: Sabine Schleiermacher - Udo Schagen (eds.), Die Charité im Dritten Reich. Zur Dienstbarkeit medizinischer Wissenschaft im Nationalsozialismus, Paderborn - München - Wien - Zürich 2008, s. 37-50, zde s. $37-38$.

6 Pro přehled použitých zákonných předpisů v jednotlivých fázích v Německu do roku 1939 srov. Ursula FERDINAND, Vertreibungen im Umgestaltungsprozess der Medizinischen Fakultäten an deutschen Universitäten 
(Gesetz zur Wiederherstellung des Berufsbeamtentums), príijatého již 7. dubna 1933.7 Jasně zglajchšaltovaných obrysů pak nabyla personální politika zejména po zavedení vůdcovského principu (Führerprinzip) a přijetí směrnic ke sjednocení vysokoškolské správy z roku 1935. ${ }^{8}$ Pro tzv. odžidovštění (Entjudung) či arizaci (Arisierung) vysokých škol, univerzit a ostatních vědeckých pracovišt', které probíhalo v Německu v několika vlnách a bylo de facto ukončeno roku 1939, se dobově užívalo vícero, zpravidla cynicky eufemistických označení. Bylo to napríklad vyřazení (Ausschaltung), odstranění (Entfernung), ale také očištění (Reinigung), očista (Purifikation) či nijak nezakrytě čistka (Säuberung). Podstatou bylo vždy vyloučení a následné odstranění dané skupiny z určitých profesních a společenských pozic, a to omezením či spíše zamezením práv jak k výkonu stávajícího povolání, tak k dalšímu obsazení určitých pozic, a tím i konsekventnímu pokračování či zahájení kariéry v akademické oblasti. Ruku v ruce s omezením občanských a lidských práv šla sociální degradace, doprovázená psychickým i fyzickým terorem, a v neposlední řadě také zničením hospodářské existence. ${ }^{9}$

Odpor z řad nežidovských kolegů byl přitom minimální, naopak z jejich strany často docházelo k bezskrupulóznímu obsazování „uvolněných“ postů. ${ }^{10}$ Jak o tomto „sebezglajchšaltování“ (Selbstgleichschaltung) lapidárně poznamenal jeden z postižených vědcủ a zároveň signatáŕ apelu Urgent Call for Unity z roku 1932, heidelberský matematik a statistik Emil Julius Gumbel (1891-1966): „Idea univerzity se rozplynula pred výpočtem penzi." "11

Přitom již v první vlně (1933-1935) bylo v Německu z akademické sféry propuštěno celkem 1145 osob, respektive 1684 osob včetně mimouniverzitních ústavů císaře Viléma (Kaiser-Wilhelm-Institute), vědeckých akademií, muzeí atd.; počet židovských vědců a akademiků se odhaduje asi na 800.12

Zůstaneme-li jen u lékařských fakult, byl celý proces, jakkoli odlišně probíhal na jednotlivých fakultách, velmi rychlý a ztráty enormní. ${ }^{13}$ Tak například na berlínské lékařské fakul-

im „,Dritten Reich“, in: Thomas Beddies - Susanne Doetz - Christoph Kopke (eds.), Jüdische Ärztinnen und Ärzte im Nationalsozialismus (= Europäisch-jüdische Studien, Bd. 12), Berlin - Boston 2014, s. 117-149, zde s. 134-135 (tabulka); k úloze studentů tamtéž, s. 126-128; P. T. WALTHER, Entlassungen und Exodus, s. 43-46. Obecně srov. také Jiří PЕŠEK, Nacifikace německých univerzit, Dějiny a současnost 17/3, 1995, s. 33-37. K vývoji protižidovského zákonodárství v Německu srov. Cornelia Essner, Die „Nürnberger Gesetze “ oder die Verwaltung des Rassenwahns 1933-1945, Paderborn 2002.

7 U. Ferdinand, Vertreibungen, s. 134. Srov. také Karel Litsch, Nacistické rasové právní předpisy na nèmeckých vysokých školách v letech 1933-1935, Acta Universitatis Carolinae - Historia Universitatis Carolinae Pragensis (dále AUC-HUCP) 2/2, 1961, s. 141-147.

8 Dieter Langewiesche - Heinz-Elmar Tenorth (eds.), Handbuch der deutschen Bildungsgeschichte, Bd. 5, 1918-1945. Die Weimarer Republik und die nationalsozialistische Diktatur, München 1989, s. 20, 228. Srov. rovněž Helmut HeiBer, Universität unterm Hakenkreuz, Bd. II, München - London - New York - Paris 1992, s. $148-260$.

9 Obecně srov. Irmtrud WoJaK (ed.), Nationalsozialismus. Volksgemeinschaft, Raub und Gedächtnis, Frankfurt/ Main - New York 2000. Dále srov. Udo Schagen, Wer wurde vertrieben? Wie wenig wissen wir? Die Vertreibungen aus der Berliner Medizinischen Fakultät 1933. Ein Überblick, in: S. Schleiermacher - U. Schagen (eds.), Die Charité im Dritten Reich, s. 37-50.

10 Pro situaci v Heidelbergu srov. Wolfgang U. ECKART, Medizin in der NS-Diktatur. Ideologie, Praxis, Folgen, Wien - Köln - Weimar 2012, s. 112-114.

11 D. Langewiesche - H.-E. Tenorth (eds.), Handbuch, s. 227.

12 Edward Y. Hartshorne, The German Universities and National Socialism, London 1937, s. 112. Srov. také D. LANGewiesche - H.-E. Tenorth (eds.), Handbuch, s. 225.

13 U. Ferdinand, Vertreibungen, s. 135. Dále srov. Wolfgang U. ECKART, Die Medizinische Fakultät, in: Wolfgang U. Eckart - Volker Sellin - Eike Wolgast (eds.), Die Universität Heidelberg im Nationalsozialismus, 
tě muselo odejít 135 z 331 a na vídeňské lékařské fakultě po připojení Rakouska dokonce 175 z celkem 321 ,nežádoucích“ (rasově i politicky) pedagogů. ${ }^{14} \mathrm{~V}$ této souvislosti je důležité připomenout, že první pokusy o podání celkového přehledu a zároveň upozornění na pronásledování těchto kolegů učinili již roku 1934 čeští lékaři v čele s profesorem Lékařské fakulty Univerzity Karlovy Janem Bělehrádkem (1896-1980). ${ }^{15}$

Kvalitativní ztráta pro evropskou a světovou vědeckou komunitu přitom byla ještě větší nežli kvantitativní. Svá působiště muselo opustit celkem dvacet nositelů Nobelovy ceny. Ze známých lékařo̊ uved'me například př́iborského rodáka Sigmunda Freuda (1856-1939), dále Hanse Adolfa Krebse (1900-1981), Fritze A. Lipmanna (1899-1986), Ottu Loewiho (1873-1961), Maxe Bielschowského (1869-1940), Alfreda Bielschowského (1871-1940), Arthura Eichengrüna (1867-1949), Ernsta Gräfenberga (1881-1957), Hanse W. Kosterlitze (1903-1996), Bernarda Katze (1911-2003) a mnohé další. ${ }^{16}$

Vedle těchto světoznámých jmen je ovšem povědomost o dopadu na jednotlivé vědecké oblasti, medicínu nevyjímaje, velmi omezená. Obdobně je jen velmi málo známo o osudu habilitujících se akademiků či doktorandech. ${ }^{17}$

\section{Lékařská fakulta Německé univerzity v Praze}

Tato fakulta zůstávala i v meziválečném období významným střediskem praktické medicíny a její kliniky nabízely často nejprogresivnější péči v Čechách. ${ }^{18} \mathrm{Ke}$ konci třicátých let byla největší fakultou celé pražské německé univerzity, když právě v druhé polovině tohoto desetiletí jí výrazně přibylo inskribovaných studentů; jejich nejvyšší počet dosáhl až přibližně $2400 .{ }^{19} \mathrm{Na}$ jednoho učitele tak v průměru připadalo 22,7 studenta. ${ }^{20}$

V době emancipace židovského obyvatelstva, která v rakousko-uherské monarchii proběhla po roce 1848, se pražská německá lékařská fakulta stala díky německému jazyku, šiři

Heidelberg 2006, s. 641-649.

14 U. Schagen, Wer wurde vertrieben?, s. 58-64; Klaus TAschwer, Hochburg des Antisemitismus. Der Niedergang der Universität Wien im 20. Jahrhundert, Wien 2015, s. 210-211.

15 Srov. Liste der Professoren der Medizin und der medizinischen Forschern, die von der Hitler-Regierung als minderwertig beurlaubt, in den Ruhestand versetzt oder verhaftet wurden, Internationales Ärztliche Bulletin 1/1, 1934, s. 12-15. Detailně je dokumentována např. situace v Berlíně. Srov. Michael HuBENSTORF, Die 19331935 entlassenen Hochschullehrer der Medizin in Berlin, in: Wolfram Fischer - Klaus Hierholzer - Michael Hubenstorf - Peter Th. Walther - Rolf Winau (eds.), Exodus der Wissenschaften aus Berlin, Berlin - New York 1994, s. 618-626. Pro mimouniverzitní sféru srov. také Peter Th. Walther, „,Arisierung “, Nazifizierung und Militarisierung. Die Akademie im „Dritten Reich“, in: Wolfram Fischer (ed.), Die Preußische Akademie der Wissenschaften zu Berlin 1914-1918, Berlin 2000, s. 101-106.

16 D. Langewiesche - H.-E. Tenorth (eds.), Handbuch, s. 227. Srov. také Heimat und Exil. Emigration deutscher Juden nach 1933, Frankfurt/Main 2006. K významu židovských lékařŭ pro lékařské vzdělání v Německu srov. Albrecht Scholz - Caris-Petra Heidel, Medizinische Bildung und Judentum, Dresden 1998.

17 U. Schagen, Wer wurde vertrieben?, s. 58-64.

18 Jiř́ PešEK - Alena MišKovÁ - Petr SvoBodnÝ - Jan JANKo, Německá univerzita v Praze v letech 1918-1939, in: Jan Havránek - Zdeněk Pousta (eds.), Dějiny Univerzity Karlovy, IV, Praha 1998, s. 181-232; Petr Svobodný, Periferie nebo centrum? Misto fakultnich nemocnic v rámci zdravotnictví a vysokého školství středoevropské metropole, Documenta Pragensia, Praha 2002, s. 425-447.

19 J. PešEK - A. MišKovÁ - P. SvobodnÝ - J. JanKo, Německá univerzita v Praze, s. 182.

20 Václav PoDANÝ, K problematice německé vědecké obce v Československu v letech 1918-1938, Dějiny věd a techniky 29/4, 1997, s. 217-227, zde s. 225. K problematice osudu židovských lékařů z Čech a Moravy během nacistické okupace a holocaustu se věnuje především probíhající výzkum Mgr. Šimona Krýsla ze Zdravotnického muzea Národní lékařské knihovny v Praze. 
profesního uplatnění i dalším faktorům pro lékaře židovského původu velmi přitažlivou. ${ }^{21}$ Po roce 1918 se dokonce zdálo, že Ministerstvo školství a národní osvěty (dále jen MŠANO) uplatňovalo personální politiku sui generis, která akademiky židovského původu na německé lékařské fakultě zvýhodňovala. Tento postup byl MŠANO opakovaně vyčítán především ze strany německy mluvících nacionálních a völkisch orientovaných kruhů. Již ve dvacátých letech a počátkem let třicátých nebyl antisemitismus $\mathrm{v}$ těchto sférách ničím neobvyklým, jak o tom svědčí např́iklad známá tzv. Steinherzova aféra, která propukla po zvolení prvního rektora Německé univerzity v Praze židovského původu, historika Samuela Steinherze (1857-1942). ${ }^{22}$

V posledním „neturbulentním“ semestru, tzn. letním semestru akademického roku 1937/1938, nabízela fakulta na svých ústavech a klinikách v rámci studia medicíny devatenáct specializací. ${ }^{23}$ Kvalita pedagogického sboru byla i v tomto období dána vývojem v předcházejícím období, kdy německá věda nejen ve střední Evropě zřetelně dominovala a kdy rovněž v oblasti lékařských oborů dosahovala mobilita akademiků značné intenzity. Časté přesuny lze před rokem 1918 doložit především mezi Prahou a Vídní, ale také směrem k některým německým univerzitám, jako např́klad Heidelbergu, Freiburgu a Vratislavi. ${ }^{24}$ Tento trend, kdy německy mluvící akademici z pochopitelných příčin migrovali více nežli jejich čeští kolegové, do značné míry přetrvával i po roce $1918 .{ }^{25}$

Nástup nacismu v Německu vedl na pražské německé univerzitě $\mathrm{k}$ jasné radikalizaci a polarizaci jak $v$ rámci celé univerzity, tak i pedagogického sboru Lékařské fakulty Německé univerzity v Praze. Pronacistická skupina se zde poněkud překvapivě zformovala okolo některých starších profesorů, jako např́klad anatoma Otty Großera (1873-1951), otolaryngologa Karla Ammersbacha (1884-1952) či internisty Waltera Nonnenbrucha (1887-1955). Kromě obšírně prezentovaných a reflektovaných incidentů (Kelsenova aféra) se do dalších

21 Pro specifickou roli pražské lékařské fakulty vůči židovskému ghettu srov. Guido Kisch, Die Prager Universität und die Juden 1348-1848. Mit Beiträgen zur Geschichte des Medizinstudiums, Amsterdam 1969, s. 36-47. V obecném přehledu srov. Helena KrejčovÁ, Juden in den 30er Jahren des 20. Jahrhunderts, in: Marek Nekula - Walter Koschmal (eds.), Juden zwischen Deutschen und Tschechen. Sprachliche und kulturelle Identität in Böhmen 1800-1945 (= Veröffentlichungen des Collegiums Carolinum, Bd. 104), München - Oldenbourg 2006, s. 85-103; k postavení na Německé univerzitě v Praze srov. Alena MíšKová, Die Lage der Juden an der Prager Deutschen Universität, in: Jörg K. Hoensch (ed.), Judenemanzipation - Antisemitismus - Verfolgung in Deutschland, Österreich-Ungarn, den böhmischen Ländern und in der Slowakei, Essen 1999, s. 117-127. Dále srov. také Petr Svobodný, Lékaři v českých zemích 1848-1939, in: Petr Svobodný - Jan Havránek, Profesionalizace akademických povolání v českých zemích v 19. a první polovině 20. století, Praha 1996, s. 126-146, zde s. 133-144.

22 Alena MíšKovÁ, Die Deutsche (Karls-) Universität vom Münchener Abkommen bis zum Ende des Zweiten Weltkrieges. Universitätsleitung und Wandel des Professorenkollegiums, Praha 2007, s. 42.

23 Byly jimi: 1. anatomie a histologie, 2. fyziologie, 3. fyziologická a lékařská chemie, 4. patologická anatomie, 5. obecná anatomie, 6. farmakologie a farmakognosie, 7. interní medicíny, 8. rentgenologie, 9. psychiatrie a neurologie, 10. pediatrie, 11. chirurgie, 12. gynekologie, 13. oční lékařství, 14. otolaryngologie (ORL), 15. zubní lékařství, 16. dermatologie a syfilis, 17. soudní lékařství, 18. průmyslové lékařství a 19. dějiny lékařství a př́rodních věd. Srov. Vorlesungsverzeichnis der Medizinischen Fakultät der Deutschen Universität in Prag - Sommer 1938/1939, Praha 1938.

24 Ludmila HlaváČKOVÁ, Lehrer der Prager deutschen medizinischen Fakultät an der Frankfurter Universität, in: Juliane C. Wilmanns - Gert Preiser (eds.), Medizin in Frankfurt am Main. Ein Symposium zum 65. Geburtstag von Gert Preiser, Hildesheim 1994 (= Frankfurter Beiträge zur Geschichte, Theorie und Ethik der Medizin, 15), s. 233-238. Srov. také Christian von FERBER, Die Entwicklung des Lehrkörpers der deutschen Universitäten und Hochschulen 1864-1954, Göttingen 1956.

25 V. PodanÝ, K problematice německé vědecké obce, s. 217, 220, 224, 227. 
roztržek $\mathrm{s}$ antisemitským podtextem zapojili i lékaři (Wilhelm Jaroschy $\mathrm{v}$ „Rede- und Lesehalle"). ${ }^{26}$

K otevřenému střetu došlo bezprostředně před mnichovskou krizí v záŕí 1938, když přibližně polovina celého profesorského sboru německé univerzity odešla do Mnichova a Vídně. Tato akce byla naplánována ve spolupráci se Sudetoněmeckou stranou (Sudetendeutsche Partei) a nacistickou organizací NS-Dozentenbund. ${ }^{27} \mathrm{Z}$ Lékařské fakulty Německé univerzity v Praze odešli mimo jiné již zmiňovaní $\mathrm{W}$. Nonnenbruch a K. Ammersbach i fyziolog Armin von Tschermak-Seysenegg, dermatolog Rudolf Bezecny (1901-1945), Anton M. Marx (1886-1939) a dokonce také jeden profesor židovského původu, jímž byl patolog Hans Rotky (1879-1965). ${ }^{28}$ Celkem v této době opustilo Prahu čtyřicet sedm ze sto pěti profesorů všech fakult německé univerzity. ${ }^{29}$ Pokud jde o lékaře, ti kteří zůstali, se ujali vedoucích pozic (např́klad na pediatrických klinikách). ${ }^{30}$ Odešla i značná část lékařského personálu, který pak bylo nutno doplnit českými zaměstnanci. ${ }^{31} \mathrm{~V}$ této době lze také pozorovat jasné rozlišování na základě „rasových“ kritérií: například německé velvyslanectví v Praze pečlivě sledovalo, kdy se přednostou nějaké kliniky stal židovský lékař a podávalo o tom relace do Berlína. ${ }^{32}$

Po přijetí mnichovského diktátu došlo ke zvýšení neformálního tlaku ze strany nacistického Německa na pokud možno co nejrychlejší odstranění vysokoškolských pedagogů židovského původu. Úspěchu tyto snahy dosáhly v lednu 1939, kdy byly v podstatě během jednoho měsíce učiněny všechny nezbytné administrativní kroky. Příslušný oběžník, o den později následovaný dalš́ konkretizací a doplňkovým výkladem, rozeslalo MŠANO všem dotčeným institucím 26. ledna 1939.33 Odvolání kvůli rasovému původu bylo kamuflováno jako předčasné penzionování či odchod na vlastní žádost. V př́ipadě, že dotčený odporoval, bylo na př́slušném rektorátu, aby zasáhl. O tom, že se nepředpokládaly komplikace, svědčí skutečnost, že závěrečná zpráva měla být podána MŠANO do 15. března 1939. Protestovali však pouze jednotlivci (Oskar Fischer). K 4. únoru 1939 byli vědci židovského původu vyloučeni rovněž z další ústřední německé instituce pro vědu a umění v Československu, Německé společnosti věd a umění pro Československou republiku (Deutsche Gesellschaft der Wissenschaften und Künste für die Tschechoslowakische Republik); jednalo se celkem o osm jejích řádných členů. ${ }^{34}$

26 Tamtéž, s. 38.

27 J. PešEK - A. MíšKovÁ - P. Svobodný - J. Janko, Německá univerzita v Praze, s. 185-187. Srov. také Věra VomÁčKovÁ, Německá universita v Praze mezi Mnichovem a 15. březnem 1939, AUC-HUCP 4, 1963, s. 3-19, zde s. 7-11; A. MíšKovÁ, Die Deutsche (Karls-) Universität, s. 46-53.

28 A. MíšKovÁ, Die Deutsche (Karls-) Universität, s. 51.

29 Tamtéž, s. 48.

30 Tamtéž, s. 51-52.

31 Politisches Archiv des Auswärtigen Amtes Berlin, f. Deutsche Gesandtschaft Prag, kniha 70, zprávy o situaci na německých lékařských klinikách v Praze z 3. a 21. 10. 1938. Viz A. MíšKová, Die Deutsche (Karls-) Universität, s. 53.

32 Politisches Archiv des Auswärtigen Amtes Berlin, f. Deutsche Gesandtschaft Prag, kniha 70, zprávy o situaci na německých lékařských klinikách v Praze z 3. a 21. 10. 1938.

33 Oběžník MŠANO č. 30 621/39, 27. 2. 1939. Srov. A. MíšKová, Die Deutsche (Karls-) Universität, s. 62.

34 Michael NeumüLlER, Überblick über die Geschichte der Gesellschaft zur Förderung deutscher Wissenschaft, Kunst und Literatur in Böhmen bzw. der Deutschen Akademie der Wissenschaften in Prag von der Gründung bis zum Jahre 1945, in: Alena Míšková - Michael Neumüller, Die Gesellschaft zur Förderung deutscher Wissenschaft, Kunst und Literatur in Böhmen (Deutsche Akademie der Wissenschaften in Prag) 1891-1945. Materialien zu ihrer Geschichte und Inventar des Archivbestandes (= Studia Historiae Academiae Scientiarum 
Tato tzv. čistící akce (Reinigungsaktion), jak bylo odstranění vysokoškolských pedagogů židovského původu německými místy interně nazýváno a jež započala ještě za existence Česko-Slovenska, byla v závěrečné fázi dozorována šéfem SD Reinhardem Heydrichem (1904-1942). Podle jeho závěrečné zprávy byla právě lékařská fakulta nejvíce postiženou ze všech fakult, nebot' z dvaceti ordinariátů zůstalo obsazeno pouze šest, což znamenalo, že obsazeno bylo vedení pouze dvou z deseti ústavů a pouze šest z dvanácti klinik mělo svého přednostu. ${ }^{35}$ Celkem pro lékařskou fakultu zpráva uváděla nucený odchod padesáti osmi židovských pedagogů. ${ }^{36}$ Do listopadu 1939 se tak jednalo o největší politicky motivovanou intervenci do složení univerzitní a vědecké komunity v českých zemích. ${ }^{37}$ Pro úplnost dodejme, že paralelně k ní byli vědci židovského původu registrováni i na českých vysokých školách. ${ }^{38}$

\section{Emigrace/exil}

Za těchto okolností se mnozí z postižených pedagogů rozhodli zemi opustit, nebot' v daný okamžik se pro ně jako hlavní možnost dalšího uplatnění nabízela pouze rekvalifikace a přeškolování. ${ }^{39}$

V případě českých zemí byla možnost odchodu v podstatě omezena pouze na období několika měsíců před rozpoutáním druhé světové války 1. záŕí 1939. Obecně lze říci, že ti, kteří se po únoru 1939 (nebo již dříve) rozhodli odejít, se na jedné straně potýkali s obdobnými problémy, s nimiž se již dřive museli vypořádat jejich kolegové z Německa a Rakouska;40 na druhé straně ovšem byla jejich situace o to těžší, že patřili k již následné

Bohemicae 7/B), Praha 1994, s. 35-50, zde s. 41-42. Srov. také V. VomÁčKovÁ, Německá universita v Praze, s. 14.

35 Tamtéž, s. 9, 10. Míšková uvádí celkový počet o patnáct menší, srov. A. MíšKovÁ, Die Deutsche (Karls-) Universität, s. 64. Rozdíl mohl vzniknout při užším výběru např. nezapočítáním penzionovaných pracovníků. V některých případech je rovněž složité rozlišit, zda hlavním důvodem byl nežádoucí rasový původ či politické angažmá. Pro NU a DTH srov. také Národní archiv (dále NA) Praha, f. ÚŘP-ST AMV 109, b. 24, sig. 109-4/206, situační zpráva za období červen - červenec 1940, 26. 7. 1940.

36 BAarch Berlin, f. R43II/1324, zpráva včetně Pamětního spisu Heydricha Göringovi, Bormannovi, Scheelovi, Schultzemu a Mentzelovi, 25. 5. 1939, s. 8.

37 Petr Svobodný, Důsledky 17. listopadu 1939 pro české lékařské fakulty, Časopis lékařủ českých 133/8, 1994, s. 245-248. Srov. také Tomáš PASÁK, 17. listopad 1939 a Univerzita Karlova, Praha 1997.

38 Archiv Národního muzea Praha, f. Kapras J., složka 4963-4971, seznam židovských učitelských sil, s. d. Na zvláštní soupis se tak dostali tři profesoři a pět docentů z pražské Univerzity Karlovy a jeden profesor na brněnské Masarykově univerzitě. Pozice J. Kaprase je velmi pikantní, nebot' šlo nejen o přímého kolegu, ale později byl veřejně nevybíravě difamován coby přední československý zednár. Srov. Walter JACOBI, Golem metla Čechi̊. Rozklad českého nacionalismu, Praha 1942, s. 88-89.

39 Punkte: Umschichtung - Geistige Voraussetzungen, Jüdisches Nachrichtenblatt 1/2, 1. 12. 1939, s. 1; Willy SchÖNFELD, Umschichtung. Der Lehrplan der Kurse, tamtéž, s. 4.

40 K problematice vědeckého exilu srov. Herbert A. STrauss, Wissenschaftsemigration als Forschungsproblem, in: týž (ed.), Die Emigration der Wissenschaften nach 1933. Disziplingeschichtliche Studien, München - London - New York - Paris 1991, s. 9-23. K situaci v Československu obecně srov. Louise LondonovÁ, Britská vláda a židovšti uprchlíci z Československa, in: Terezínské studie a dokumenty (TSD) 2003, s. 106-134; Peter Heumos, Die Emigration aus der Tschechoslowakei nach Westeuropa und dem nahen Osten 1938-1945. Politisch-soziale Struktur, Organisation und Asylbedingungen, München 1989. K situaci akademiků a lékařů srov. Soňa ŠTrbÁŇOvÁ, Českoslovenští biochemici ve Velké Británii v letech 1939-1945, in: Antonín Kostlán (ed.), Semináře a studie k dějinám vědy, Praha 2009, s. 109-133; Paul J. Weinduing, Czechoslovak Medical Refugees in Great Britain During and After Second World War, in: Antonín Kostlán - Alice Velková (eds.), Wissenschaft im Exil. Die Tschechoslowakei als Kreuzweg 1918-1989 (= Studies in the History of Sciences and Humanities, 
vlně uprchlíků, při níž se možnosti plánování a výběru dramaticky snížily. ${ }^{41}$ Značně redukované tak samozřejmě byly i možnosti nové kariéry v zahraničí.

Emigrace předpokládala naprosto osudové rozhodnutí, které se netýkalo pouze samotných akademiků, ale také jejich užší či širší rodiny. Navíc muselo být podepřeno finančně (dostatkem deviz) a především musela vůbec existovat reálná možnost kam odejít, respektive kde se následně usadit. ${ }^{42} \mathrm{~V}$ převážné většině zemí, jež v danou dobu přicházely v úvahu, přitom platily restriktivní uprchlické kvóty a proti přijímání se z partikulárních zájmů tu více tu méně otevřeně stavěly i domácí profesní a stavovské organizace. Výhledy těch, kteří se rozhodli pro odchod, jednoduše nebyly nikterak záviděníhodné. Hlavním motivem tak zpravidla zůstávalo zachránění vlastní fyzické existence, jež však bylo vykoupeno profesní degradací a spojeno s mnoha nepřekonatelnými obtížemi. ${ }^{43}$ Tak např́iklad British Medical Association chápala až do ledna 1941 pobyt emigrantů z řad židovských lékařů ve Velké Británii jako dočasný a neumožňovala jim získání permanentního povolení k výkonu praxe. ${ }^{44}$ Dlouhodobý př́nos jejich působení si byl v této době i v odborných kruzích ochoten zkrátka připustit málokdo. Např́klad lord Bertrand Edward Dawson, první vévoda z Pennu (1864-1945) a prezident britské Royal College of Physicians, který roku 1933 na adresu emigrantů-lékařu z Německa rezolutně prohlásil, že ,počet těch, kteři by mohli být účelně začleněni a něco nás naučit, by bylo možné spočitat na prstech jedné ruky“. ${ }^{45}$

Celkové zpracování lékařské emigrace ovšem doposud stále chybí. Zatímco pro humanitní obory jsou k dispozici přehledy již z šedesátých let 20. století, první soupisy pro lékařské

Vol. 17), Praha 2004, s. 52-65; Gerhard Hirschfeld, Zuflucht in Großbritanien. Zur Emigration deutschsprachiger Prager Wissenschaftler nach 1938, in: Peter Becher - Peter Heumos (eds.), Drehscheibe Prag. Zur deutschen Emigration in der Tschechoslowakei 1933-1939 (= Veröffentlichungen des Collegium Carolinum, Bd. 75), München 1992, s. 75-86. Dále srov. také Antonín Kostlán - Soňa ŠtrbáŇová, Czech Scholars in Exile, 1948-1989, in: Proceedings of the British Academy 169, 2011, s. 239-256.

41 Anna E. von Villiez, Emigration jüdischer Ärzte im Nationalsozialismus, in: T. Beddies - S. Doetz - Ch. Kopke (eds.), Jüdische Ärztinnen und Ärzte, s. 190-202, zde s. 191; Juliane Wetzel, ,Auswanderung aus Deutschland", in: Wolfgang Benz (ed.), Die Juden in Deutschland 1933-1945. Leben unter nationalsozialistischer Herrschaft, München 1989, s. 413-431, 477-497; Doron Niderland, Emigration of Jewish Academics and professionals from Germany, Leo Baeck Institute Year Book 18, 1988, s. 294-315.

42 Pro situaci v USA srov. Claus-Dieter CROHN, American Foundations and Refugee Scholars between the Two Wars, in: Giuliana Gemelli (ed.), The 'Unacceptables'. American Foundations and Refugee Scholars between the Two Wars and after (= Euroclio 18), Bruxelles 2000, s. 35-51; Richard Breitman - Alan M. Kraut, American Refugee Policy and European Jewry, 1933-1945, Bloomington 1987; David L. Edsall - Tracy J. Putnam, The Emigré in America, 1941. A Report of the National Committee for Resettlement of Foreign Physicians, in: Kathleen M. Pearle, Preventive Medicine. The Refugee Physician and the New York Medical Community 1933-1945 (= Working Papers on Blocked Alternatives in the Health Policy, Vol. 11), Bremen 1981, s. 210-242. Pro situaci ve Velké Británii srov. Louise London, Whitehall and the Jews 1933-1948. British Immigration Policy and the Holocaust, London 2002, s. 25-58; Bernard WASSERSTEIN, Britain and the Jews of Europe 1939-1945, Oxford - New York 1979; Ari J. Sherman, Island Refuge. Britain and the Refugees from the Third Reich, 1933-1939, Portland 1973. K vědecké emigraci srov. také Jean S. MEdawar - David PyKe, Hitlers's Gift. The True Story of the Scientists Expelled by the Nazi Regime, New York 2000.

43 W. U. ECKART, Medizin in der NS-Diktatur, s. 111.

44 P. J. Weindling, Czechoslovak Medical Refugees, s. 58-59.

45 Cit. dle A. J. Sherman, Island Refuge, s. 48. K dopadu působení emigrantů v přijímacích zemích srov. Albert SchOlZ - Caris-Petra Heidel (eds.), Emigrantenschicksale. Einfluß der jüdischen Emigranten auf Sozialpolitik und Wissenschaft in den Aufnahmeländern (= Medizin und Judentum, Bd. 7), Frankfurt/Main 2004; David PYкE, Contributions by German émigrés to British medical science, Quarterly Journal of Medicine 93, 2000, s. 487-495. 
obory se objevily až později a dodnes vlastně nejsou kompletní ${ }^{46}$ Pro Německo se počet odhaduje mezi 6000 až 6500, z Rakouska 2400-2600 a z Československa 300-350 emigrovavších lékařŭ. ${ }^{47}$ Tento odhad ovšem bude značně podhodnocen, nebot' jen pro Velkou Británii je podchyceno 472 (389 mužů a 83 žen $)^{48}$ lékařů s československou státní př́slušností, čímž na britských ostrovech početně predstavovala čtvrtou největší skupinu mezi emigranty-lékaři z kontinentu. ${ }^{49}$ Přitom je třeba upozornit na velmi rozdílné zpracování osudů akademických lékařských elit na jedné a praktikujících lékařů na druhé straně.

Podle autorových rešerší zvolilo následkem popsaného vývoje emigraci celkem dvanáct mimořádných či rádných profesorů a čtrnáct docentů z Lékařské fakulty Německé univerzity v Praze ${ }^{50} \mathrm{~V}$ obou těchto podskupinách byl jeden vědec, který emigroval tak, že se nevrátil ze stáže či studijního pobytu, na který odjel již před záŕím 1938. Jednalo se o chemika Heinricha Benedicta Waelsche (1905-1966) a internistu Waltera Redische (1898-1993), kteří oba zůstali v New Yorku, konkrétně na Columbia University (Waelsch) a New York University School of Medicine (Redisch). ${ }^{51}$

Průměrný věk profesorů $\mathrm{v}$ době emigrace byl padesát let, průměrný věk docentů čtyřicet osm let. Lze předpokládat, že naprostá většina akademiků emigrovala v roce 1939. Jednalo se o představitele těchto lékařských oborů: oftalmologie, gynekologie, pediatrie, sociální/pracovní lékařství a hygiena, lékařská, fyzikální a farmaceutická chemie, dermatologie, rentgenologie, hematologie, interní lékařství, patologická anatomie a fyziologie a bakteriologie.

Po odchodu se tito pedagogové usadili v Evropě (Velká Británie, Nizozemí, Norsko a Turecko), v Severní a Jižní Americe (USA, Argentina), v Africe (Egypt), na Středním

46 Obecně srov. Wilhelm Sternfeld - Eva Tiedemann, Deutsche Exil-Literatur 1933-1945. Eine Bio-Bibliographie, Heidelberg - Darmstadt 1962; Claus Dieter KROHN - Patrik von zur MüHLEN - Gerhard PAUL - Lutz WinCKLER (eds.), Handbuch der deutschsprachigen Emigration 1933-1945, Darmstadt 1998; Fred BILENKIS Hannah CAPLAN (eds.), Biographisches Handbuch der deutschsprachigen Emigration nach 1933 (= International Biographical Dictionary of Central European Emigrés 1933-1945, Vol. 1.-3.), München 1999. Pro lékaře srov. Hans-Peter KRÖNER, Emigration deutschsprachiger Mediziner im Nationalsozialismus (= Berichte zur Wissenschaftsgeschichte, Bd. 12), Weinheim 1989; Peter ScHNECK, Zur Frage des Exils von Wissenschaftlern deutscher medizinischer Fakultäten in der Zeit des Faschismus - Eine quantifizierende Untersuchung, Zeitschrift für die gesamte Hygiene 31, 1985, s. 306-309. K osudu farmakologů srov. Konrad LöFfELHOLZ - Ullrich TRENDELEnBuRG, Verfolgte deutschsprachige Pharmakologen 1933-1945, Frechen 2008.

47 H.-P. KRÖNER, Emigration deutschsprachiger Mediziner, s. 15; W. U. ECKART, Medizin in der NS-Diktatur, s. 111.

48 Ke specifické skupině lékařek srov. Anna E. von ViLliez, The Emigration of Women Doctors from Germany under National Socialism, Social History of Medicine 22/3, 2009, s. 553-567, a Atina GrossmanN, New Women in Exile. German Women Doctors and the Emigration, in: Sybille Quack (ed.), Between Sorrow and Strength. Women Refugees of the Nazi Period, Washington, D. C. - Cambridge 1995, s. 215-239.

49 P. J. Weindling, Czechoslovak Medical Refugees, s. 53-54. Pro situaci ve Velké Británii dále srov. TÝž, Medical Refugees and the Modernisation of British Medicine, 1930-1960, Social History of Medicine 22/3, 2009, s. 489-511, a Karola DeCKer, Divisions and diversity. The complexities of medical refugee in Britain, 1933-1948, Bulletin of the History of Medicine 77, 2003, s. 850-873.

50 Míšková uvádí celkem 15 profesorů a 26 docentů. Srov. A. MišsovÁ, Die Deutsche (Karls-) Universität, s. 64. Rozdíl mohl vzniknout nejen upřesněním některých údajů, ale také dvojí afiliací apod.

51 K působení v USA srov. Joel Elkes, Heinrich Waelsch, 1905-1966, Psychopharmacologica 10/4, 1967, s. 285-288; Hans Weil-MalHerBe, Heinrich Waelsch, Experimental Brain Research 2/1, 1966, s. 1-3, a Wolfgang Saxon, Walter Redisch, 94. A Professor Known for Research Work, The New York Times, 14. 1. 1993. Dále srov. biografická hesla in: Ludmila HLAvÁčKovÁ - Petr SvobodnÝ, Biographisches Lexikon der Deutschen Medizinischen Fakultät in Prag 1883-1945, Prag 1998, s. 218 a 169-170. 
východě (Palestina) a v Austrálii. V zásadě tedy bylo jejich geografické rozptýlení obdobné jako u lékařů, kteří již dř́ve museli odejít z Německa a Rakouska. ${ }^{52}$

Dochované archivní materiály bohužel poskytují podrobné informace o podmínkách emigrace jen v několika př́ípadech, a to především v těch, kdy se daný lékař snažil s sebou vyvézt vybavení potřebné pro plánovanou lékařskou praxi. Zde můžeme uvést např́klad ortopedického chirurga Wilhelma Jaroschyho (1886-1943). Tomu se podařilo emigrovat až na počátku listopadu 1939 do Norska a byl schopen zařídit i odvoz vybavení své ordinace. ${ }^{53}$ Jako druhý prominentní př́klad lze uvést profesora farmakologie a farmakognosie a posledního představitele německé farmakologické školy v Čechách Emila Starkensteina (1884-1942), patř́íího ve svém oboru k absolutní evropské špičce. Díky tomu a díky četným kontaktům se mu podařilo zajistit odchod nejen téměř celé rodiny, ${ }^{54}$ ale i přestěhování cenné odborné a historické knihovny a soukromé sbírky do Nizozemí, i když cílovou zemí měla být Velká Británie či spíše USA. ${ }^{55} \mathrm{Z}$ toho můžeme obecně usuzovat, že jen někteří lékaři doufali, že se jim podaří uplatnit se $\mathrm{v}$ zahraničí v akademické oblasti či alespoň se uchytit v lékařské praxi. Proti tomu často hovořil nejen vyšší či dokonce značně vysoký věk, kontinentální či spíše tradiční německé vzdělání a konečně také znalost, respektive neznalost cizích jazyků na odpovídající odborné úrovni.

Nové rešerše úředních dokumentů dále ukazují, že dva univerzitní učitelé, kteří v roce 1939 zažádali o víza, byli odmítnuti. Oba byli docenti psychiatrie a neurologie a usilovali o emigraci do USA. Šlo o Erwina Hirsche (1888-1944) a Franze Theodora Münzera (1895-1944); oba zahynuli v Osvětimi v roce 1944.56

Ve výčtu se objevují i jména dvou akademiků, kteří zprvu úspěšně emigrovali, ale později se dostali do zajetí $\mathrm{v}$ zemích, které si vybrali nebo v nichž shodou okolností skončili a v nichž je ovšem později válečné události dostihly. Byli jimi již uvedení profesoři W. Jaroschy a E. Starkenstein. ${ }^{57}$

\section{Holokaust/SHOAH}

Ti, kteř́ zůstali nebo kterým se roku 1939 nepodařilo odejít, byli vystaveni jak narůstajícímu vyloučení, tak i profesní a společenské izolaci. ${ }^{58}$ Bezprostředně po válce tyto aspekty velmi výstižně popsal literární historik a profesor Univerzity Karlovy Albert Pražák (1880-1956): „Vzdělanec byl brzy nejkrutěji omezen ve svém pohybu a ve své tvorbě, neměl

52 A. E. v. Villiez, Emigration jüdischer Ärzte, s. 192-199.

53 Michal V. Š ImƯNeK, Wilhelm Jaroschy, in: týž - Antonín Kostlán (eds.), Disappeared Science. Biographical Dictionary of Jewish Scholars from Bohemia and Moravia - Victims of Nazism, 1939-1945 (= Studies in the History of Sciences and Humanities, Vol. 29), Praha - Č. Kostelec 2013, s. 88-91, zde s. 90.

54 Odejít se nepodařilo synovi Walterovi (nar. 1916), který měl přes Polsko údajně odejít do SSSR; poslední informace o něm pocházejí z Ukrajiny. Srov. Michal V. ŠImŮNEK, Emil Starkenstein, in: týž - A. Kostlán (eds.), Disappeared Science, s. 195-203, zde s. 195, 200, a př́spěvek dr. Waltera van Emde-Boas při vzpomínkovém setkání v Praze u př́ležitosti 130. narozenin E. Starkensteina v září 2014.

55 Tamtéž.

56 Michal V. ŠImưNeK, Erwin Hirsch, in: týž - A. Kostlán (eds.), Disappeared Science, s. 86-87; Ludmila HLAvÁČKovÁ, Franz Theodor Münzer, in: tamtéž, s. 154-157.

57 M. V. ŠIMŮNEK, Emil Starkenstein, s. 195-203.

58 Pro archivní prameny a literaturu obětí holokaustu srov. M. V. ŠImŮNEK - A. Kostlán (eds.), Disappeared Science, s. XI-XVII a 253-289. 
brzy ani kam psát. Byl pozorován, špehován, znepokojován, činěn závislým na cizím, byl zatarasen cizí tlustou stěnou s výhledem jen na ni. “59 Vědcům a akademikům židovského původu bylo navíc z rasových důvodů zamezeno navštěvovat veřejné instituce, do nichž se mohli, jak někteří doufali, uchýlit, když dále chtěli pokračovat na svých pracích. Velmi výstižně tuto frustraci shrnul v červnu 1940 zoolog, známý cestovatel a čestný spolupracovník Národního muzea v Praze Jiří Baum (1900-1944): „Nyní v létech, kdy bych mohl plně vědecky zhodnotiti výsledek dlouholetého studia v cizině a domově, stává se mi okolnost, že jsem židovského puvodu, vážnou překáǎkou dalši vědecké práce a dokončeni spisü, kteréjiž po léta pripravuji ““60 $\mathrm{K}$ narůstající izolaci je třeba připočítat rovněž cenzurní zásahy, které se nevyhnuly ani odborné produkci a měly i zpětnou platnost. ${ }^{61} \mathrm{~V}$ souvislosti s holocaustem je důležité připomenout obdivuhodné snahy vědců a akademiků $\mathrm{v}$ rámci tzv. univerzity přežití v Terezíně. ${ }^{62}$

Zatímco v první vlně transportů do lodžského ghetta lze nalézt především vědce z Př́irodovědecké fakulty Německé univerzity v Praze, znamenal v perzekuci členů pedagogického sboru německé lékařské fakulty zlom rok $1942 .{ }^{63}$ Do konce tohoto roku zemřelo v důsledku rasového pronásledování a zahájení „,konečného řešení židovské otázky“ 50 \% všech židovských vědců a akademiků z Čech a Moravy. ${ }^{64}$

Z profesorů a docentů Lékařské fakulty Německé univerzity v Praze př̌šly během tohoto roku o život čtyři osoby. Roku 1943 následovaly dvě a 1944 pět osob. Celkem se jednalo o třináct osob; tři osoby spáchaly sebevraždu, dále se jednalo o úmrtí v terezínském ghettu (čtyři osoby) a vraždy v Osvětimi (pět osob), respektive Mauthausenu (jedna osoba). Již uvedené profesory W. Jaroschyho a E. Starkensteina dostihla nacistická okupace Norska a Nizozemí, kam předtím emigrovali. Průměrný věk nepřeživších profesorů byl šedesát šest a docentů padesát sedm let.

Z celkem šestačtyřiceti vědců, akademiků a vynálezců židovského původu z Čech a Moravy, kteří přišli během války a holocaustu o život, činil podíl členů předválečného profesorského sboru Lékařské fakulty Německé univerzity v Praze celých $28 \%$. Pro srovnání uved’me, že o dva roky později hovořily souhrny vypracované na základě zpráv zaslaných z protektorátu do Velké Británie odhadem o 15-20\% úmrtnosti českých vysokoškolských pracovníků; z toho asi polovina měla být důsledkem nacistické represe. ${ }^{65}$

Pro úplnost dodejme, že válku, okupaci a holocaust přežili tři profesoři a tři docenti Lékařské fakulty Německé univerzity v Praze židovského původu. ${ }^{66}$

59 Albert PRAžÁa, Český vzdělanec v zabrané vlasti, in: Šest let okupace Prahy, Praha 1946, s. 65-69, zde s. 66.

60 NA Praha, f. MV I-SR, k. 6581, sig. 1941-1944, 9/50/46, Baum J., žádost státnímu prezidentovi o vyjmutí z dosahu platnosti protižidovských nařízení, 1. 6. 1940.

61 Srov. Michael Wögerbauer (ed.), V obecném zájmu. Cenzura a sociální regulace literatury v moderní české kulture 1749-2014, sv. II, Praha 2015, s. 915-930.

62 Srov. Jelena G. Makarova, Univerzita přežití. Osvětová a kulturní činnost v terezinském ghettu 1941-1945, Praha 2002; тÁž, Akademie přežití, TSD 1998, s. 232-259; Livia RothкIRCHEn, Der geistige Widerstand in Theresienstadt, TSD 1997, s. 118-141.

63 Richard Seeman, Ghetto Litzmannstadt 1941-1944, Praha 2000, s. 277-278. Dále srov. Pavel Zeman, Rok 1941 - kvalitativní proměny nacistické genocidy, in: Ladislav Kudrna (ed.), Válečný rok 1941 v československém domácím a zahraničním odboji. Sborník k mezinárodní konferenci, Praha 2012, s. 155-172.

64 Srov. M. V. S̆IMŮNeK - A. Kostlán (eds.), Disappeared Science, s. 1-251 (prosopografické vyhodnocení).

65 NA Praha, f. MV-L, k. 244, sig. 2-59-27, zpráva o školských poměrech v protektorátu, 16. 10. 1944.

66 Byli to: Altschul Walter (1883-?) - docent rentgenologie, Lodž; Epstein Berthold (1890-1962) - profesor pediatrie, Osvětim; Fischer Bruno (1888-1973) - docent psychiatrie a neurologie, Terezín a Osvětim; Kohn 
Bezprostředně po skončení války byly oběti z řad vědců a akademiků židovského původu připomínány jen naprosto výjimečně. Tak například první poválečný soupis obětí z řad vysokoškolských učitelů a zaměstnanců, který byl vyhotoven před 1. srpnem 1945 a otištěn v publikaci věnované perzekuci československého studentstva za války, vydané u př́ležitosti světového kongresu studentstva v Praze ve dnech 17.-24. listopadu 1945, je opomíjel zcela. ${ }^{67}$ Mezi sedmdesáti jmény, která přinesl, se ocitlo pouze pět učenců židovského původu, kteří působili na Univerzitě Karlově v Praze. ${ }^{68}$

Toto vytěsnění mělo na jedné straně hlubší kořeny, na straně druhé souviselo rovněž s fenoménem kolektivní ,ignorant silence“ (Beschweigung) a „exteritorializace“ holocaustu, ${ }^{69}$ popřípadě dlouhodobé „sektorální amnézie““.70 Ono „nenamáhavé vyloučení osudu židư“ bylo ostatně př́iznačné i pro oficiální poválečnou komemoraci v Československu.

Tabulka 1 Přehled emigrovavších akademiků Lékařské fakulty Německé univerzity v Praze židovského původu

\begin{tabular}{|c|c|c|c|}
\hline jméno, osobní data & obor, pozice & země & doba \\
\hline $\begin{array}{l}\text { Ascher, Karl Wolfgang } \\
\text { (3. 7. 1887, Praha - 7.7.1971, Cincinnati) }\end{array}$ & $\begin{array}{l}\text { oftalmologie } \\
\text { mimořádný profesor }\end{array}$ & USA & srpen 1939 \\
\hline $\begin{array}{l}\text { Benda, Robert } \\
(24.6 .1890 \text {, Praha - 1947) }\end{array}$ & $\begin{array}{l}\text { gynekologie, porodnictví } \\
\text { docent }\end{array}$ & USA & červenec 1939 \\
\hline $\begin{array}{l}\text { Frank, Max } \\
\text { (27. 7. 1894, Olomouc - } \\
\text { 8.3. 1970, San Francisco) }\end{array}$ & $\begin{array}{l}\text { pediatrie } \\
\text { docent }\end{array}$ & USA & duben 1939 \\
\hline $\begin{array}{l}\text { Gruschka, Theodor } \\
\text { (27.6.1888, Moravský Krumlov } \\
\text {-26.6. 1967, Jeruzalém) }\end{array}$ & $\begin{array}{l}\text { hygiena, sociální lékařství } \\
\text { řádný profesor }\end{array}$ & $\begin{array}{l}\text { Palestina, } \\
\text { Izrael }\end{array}$ & 1939 \\
\hline $\begin{array}{l}\text { Haurowitz, Felix } \\
(1.3 .1896 \text {, Praha }-2.12 .1987 \text {, Bloomington })\end{array}$ & $\begin{array}{l}\text { lékařská chemie } \\
\text { mimořádný profesor }\end{array}$ & Turecko & 1939 \\
\hline $\begin{array}{l}\text { Hecht, Hugo } \\
\text { (23. 7. 1883, Praha - 1.2.1970, Cleveland) }\end{array}$ & $\begin{array}{l}\text { dermatologie } \\
\text { docent }\end{array}$ & USA & 1938 \\
\hline $\begin{array}{l}\text { Herrnheiser, Gustav } \\
\text { (6. 8. 1890, Praha - 13. 5. 1956, Londýn) }\end{array}$ & $\begin{array}{l}\text { rentgenologie } \\
\text { mimořádný profesor }\end{array}$ & $\begin{array}{l}\text { Palestina, } \\
\text { Egypt }\end{array}$ & 1939 \\
\hline
\end{tabular}

Alfred (1867-1959) - profesor histologie, Terezín; Löwy Max (1875-1948) - profesor psychiatrie a neurologie, Terezín; Stein Richard (1898-?) - docent oftalmologie, Terezín (1949 emigrace do Izraele).

67 František Kropáč - Vlastimil Louda (eds.), Persekuce českého studentstva za okupace (= Dokumenty doby, I/2), Praha 1945, s. 146-151. Srov. také kongresový materiál: Jan BĚLEHRÁDEK, Czech Learning After the War, in: World Student's Congressus “The Seventeenth of November" Prague 1945, Praha 1945, b. s.

68 F. KROPÁČ - V. Louda (eds.), Persekuce českého studentstva, s. 146-151. Srov. J. BĚLEHRÁdeK, Karlova universita, s. 13-16. Byli jimi Arnošt Kraus, Bedřich Mendl, Jan Levit, Leo Taussig a Josef Fischer.

69 Hermann LüBBE, Der Nationalsozialismus im deutschen Nachkriegsbewußtsein, Historische Zeitschrift 236/3, 1983, s. 579-599, zde s. 585; Jörn Rüsen, Holocaust, Erinnerung, Identität. Drei Formen generationeller Praktiken des Erinnerns, in: Harald Welzer (ed.), Das soziale Gedächtnis. Geschichte, Erinnerung, Tradierung, Hamburg 2001, s. 245.

70 Tohoto termínu uživají Christof CORNELISSEn - Roman HoLEC - Jiří PeŠEK, Politisch-historische Erinnerungen in Mittel- und Ostmitteleuropa seit 1945, in: Christof Cornelißen - Roman Holec - Jiří Pešek (eds.), Diktatur Krieg - Vertreibung. Erinnerungskulturen in Tschechien, der Slowakei und Deutschland seit 1945, Essen 2005, s. $9-24$. 


\begin{tabular}{|c|c|c|c|}
\hline $\begin{array}{l}\text { Jaroschy, Wilhelm } \\
\text { (6. 4.1886, Praha - 3. 3.1943 Osvětim) }\end{array}$ & $\begin{array}{l}\text { ortopedická chirurgie } \\
\text { mimořádný profesor }\end{array}$ & Norsko & 1939 \\
\hline $\begin{array}{l}\text { John, Hans } \\
\text { (27.7.1889, Broumov - 23. 2. 1942, Deventer) }\end{array}$ & $\begin{array}{l}\text { farmaceutická chemie } \\
\text { mimořádný profesor }\end{array}$ & Nizozemí & 1939 \\
\hline $\begin{array}{l}\text { Kaznelson, Paul } \\
\text { (7. 4. 1892, Varšava - 1959?) }\end{array}$ & $\begin{array}{l}\text { hematologie, vnitřní } \\
\text { medicína } \\
\text { docent }\end{array}$ & UK & 1939 \\
\hline $\begin{array}{l}\text { Klein, Otto } \\
\text { (23. 8. 1889, Plzeň - 9. 4. 1968, Buenos Aires) }\end{array}$ & $\begin{array}{l}\text { vnitřní medicína } \\
\text { mimořádný profesor }\end{array}$ & Argentina & 1939 \\
\hline $\begin{array}{l}\text { Klein, Robert } \\
\text { (10. 11.1989, Stráž u Tachova } \\
\text {-3.6.1939, Birmingham) }\end{array}$ & $\begin{array}{l}\text { psychiatr, neurolog } \\
\text { docent }\end{array}$ & UK & 1939 \\
\hline $\begin{array}{l}\text { Kraus, Erik(ch) J. } \\
\text { (2. 3. 1887, Kolín - 17. 1. 1955, Peoria) }\end{array}$ & $\begin{array}{l}\text { patologická anatomie } \\
\text { mimořádný profesor }\end{array}$ & USA & 1938 \\
\hline $\begin{array}{l}\text { Loos, Anton } \\
\text { (4. 1. 1890, Žatec - ?) }\end{array}$ & $\begin{array}{l}\text { zubní lékařství } \\
\text { docent }\end{array}$ & UK & $?$ \\
\hline $\begin{array}{l}\text { Loewenstein, Arnold } \\
\text { (4. 6. 1882, Karlovy Vary - 5. 10. 1952, } \\
\text { Glasgow) }\end{array}$ & $\begin{array}{l}\text { oftalmologie } \\
\text { mimořádný profesor }\end{array}$ & UK & 1939 \\
\hline $\begin{array}{l}\text { Löwy, Julius } \\
\text { 5. 1888, Karlovy Vary - } \\
\text { 15. 11. 1944, Londýn) }\end{array}$ & $\begin{array}{l}\text { pracovní medicína } \\
\text { mimořádný profesor }\end{array}$ & UK & 1939 \\
\hline $\begin{array}{l}\text { Raab, Wilhelm } \\
\text { (4. 1. 1889, Vídeň - 2.9. 1970, Burlington) }\end{array}$ & $\begin{array}{l}\text { patologická fyziologie } \\
\text { docent }\end{array}$ & USA & 1939 \\
\hline $\begin{array}{l}\text { Redisch, Walter } \\
\text { (26. 9. 1898, Praha - 1. 1. 1993, New York) }\end{array}$ & $\begin{array}{l}\text { vnitřní lékařství } \\
\text { docent }\end{array}$ & USA & $\begin{array}{l}1938 \\
\text { (studijní pobyt) }\end{array}$ \\
\hline $\begin{array}{l}\text { Reimann, Friedrich } \\
\text { (11. 12 1897, Mladkov } \\
\text { - 6. 8. 1994, Mnichov) }\end{array}$ & $\begin{array}{l}\text { vnitřní lékařství } \\
\text { docent }\end{array}$ & Turecko & 1939 \\
\hline $\begin{array}{l}\text { Reiss, Maximilian } \\
\text { 5. 1900, Stanislavka, Ukraine - ?) }\end{array}$ & $\begin{array}{l}\text { patologická fyziologie } \\
\text { docent }\end{array}$ & UK & 1938 \\
\hline $\begin{array}{l}\text { Singer, Ernst } \\
\text { (27. 6. 1899, Praha - 1975) }\end{array}$ & $\begin{array}{l}\text { hygiena } \\
\text { mimořádný profesor }\end{array}$ & Austrálie & 1939 \\
\hline $\begin{array}{l}\text { Spat, Wilhelm } \\
\text { (4. 3. 1874, Gródek, - ?) }\end{array}$ & $\begin{array}{l}\text { hygiena } \\
\text { docent }\end{array}$ & UK & $?$ \\
\hline $\begin{array}{l}\text { Starkenstein, Emil } \\
\text { (8. 12. 1884, Poběžovice } \\
\text {-6.11. 1942, Mauthausen) }\end{array}$ & $\begin{array}{l}\text { farmakologie, } \\
\text { farmakognozie } \\
\text { rádný profesor }\end{array}$ & Nizozemí & březen 1939 \\
\hline $\begin{array}{l}\text { Waelsch, Heinrich Benedict } \\
\text { (20. 1. 1905, Brno - 22. 3. 1966, New York) }\end{array}$ & $\begin{array}{l}\text { lékařská chemie } \\
\text { docent }\end{array}$ & USA & $\begin{array}{l}1938 \\
\text { (studijní pobyt) }\end{array}$ \\
\hline $\begin{array}{l}\text { Weiser, Egon Leopold } \\
(6.10 .1988, \text { Bukurešt' - ?) }\end{array}$ & $\begin{array}{l}\text { vnitřní lékařství } \\
\text { docent }\end{array}$ & $?$ & 1939 \\
\hline $\begin{array}{l}\text { Weleminsky, Friedrich } \\
\text { (20. 1. 1868, Golčův Jeníkov } \\
\text { - 1. 1. 1945, Londýn) }\end{array}$ & $\begin{array}{l}\text { hygiena, bakteriologie } \\
\text { docent }\end{array}$ & UK & březen 1939 \\
\hline
\end{tabular}


Tabulka 2 Přehled nepřeživších a zavražděných akademikư Lékařské fakulty Německé univerzity v Praze židovského původu

\begin{tabular}{|c|c|c|}
\hline jméno a osobní data & obor a pozice & místo smrti \\
\hline $\begin{array}{l}\text { Fischer, Oskar } \\
\text { (12. 4. 1876, Slaný - 2. 3. 1942, Terezín) }\end{array}$ & $\begin{array}{l}\text { psychiatrie, neurologie } \\
\text { mimořádný profesor }\end{array}$ & Terezín \\
\hline $\begin{array}{l}\text { Fischl, Rudolf } \\
\text { (12. 2. 1862, Vysoké Mýto - 18. 2. 1942, } \\
\text { Praha) }\end{array}$ & $\begin{array}{l}\text { pediatrie } \\
\text { řádný profesor }\end{array}$ & Praha (sebevražda) \\
\hline $\begin{array}{l}\text { Hirsch, Erwin } \\
\text { (28. 5. 1888, Karlovy Vary - 20.10. 1944, } \\
\text { Osvětim) }\end{array}$ & $\begin{array}{l}\text { psychiatrie, neurologie } \\
\text { mimořádný profesor }\end{array}$ & Osvětim \\
\hline $\begin{array}{l}\text { Jaroschy, Wilhelm } \\
\text { (16. 4. 1886, Praha - 3. 3. 1943, Osvětim) }\end{array}$ & $\begin{array}{l}\text { ortopedická chirurgie } \\
\text { mimořádný profesor }\end{array}$ & Osvětim \\
\hline $\begin{array}{l}\text { Kahn, Richard } \\
\text { (8. 7. 1876, Praha - 26. 12. 1941, Řevnice) }\end{array}$ & $\begin{array}{l}\text { fyziologie } \\
\text { mimořádný profesor }\end{array}$ & Řevnice (sebevražda) \\
\hline $\begin{array}{l}\text { Klausner, Erwin } \\
\text { (8. 9.1883, Frýdlant -6.10.1944, Osvětim) }\end{array}$ & $\begin{array}{l}\text { dermatologie } \\
\text { docent }\end{array}$ & Osvětim \\
\hline $\begin{array}{l}\text { Mahler, Paul } \\
\text { (23. 4. 1897, Praha - 17. 3. 1939, Praha) }\end{array}$ & $\begin{array}{l}\text { vnitřní lékařství } \\
\text { docent }\end{array}$ & Praha (sebevražda) \\
\hline $\begin{array}{l}\text { Münzer, Franz Theodor } \\
\text { (25. 11. } 1895 \text { Planá - po 23. 10. 1944, } \\
\text { Osvětim) }\end{array}$ & $\begin{array}{l}\text { psychiatrie, neurologie } \\
\text { docent }\end{array}$ & Osvětim \\
\hline $\begin{array}{l}\text { Přibram, Hugo } \\
\text { (4. 1. 1881, Praha - 19. 5. 1943, Terezín) }\end{array}$ & $\begin{array}{l}\text { vnitřní lékařství, patologie } \\
\text { řádný profesor }\end{array}$ & Terezín \\
\hline $\begin{array}{l}\text { Schleissner, Felix } \\
\text { (4. 2. 1874, Praha - 9. 11. 1944, Terezín) }\end{array}$ & $\begin{array}{l}\text { pediatrie } \\
\text { docent }\end{array}$ & Terezín \\
\hline $\begin{array}{l}\text { Sittig, Otto } \\
\text { (7. 9. 1886, Praha-po 28.10.1944, } \\
\text { Osvětim) }\end{array}$ & $\begin{array}{l}\text { neurologie, psychiatrie } \\
\text { mimořádný profesor }\end{array}$ & Osvětim \\
\hline $\begin{array}{l}\text { Starkenstein, Emil } \\
\text { (18. 12. 1884, Poběžovice - 6.11. 1942, } \\
\text { Mauthausen) }\end{array}$ & $\begin{array}{l}\text { farmakologie, farmakognozie } \\
\text { řádný profesor }\end{array}$ & Mauthausen \\
\hline $\begin{array}{l}\text { Stransky, Emil } \\
\text { (16. 10. 1889, Praha - 10.11. 1938, Karlovy } \\
\text { Vary) }\end{array}$ & $\begin{array}{l}\text { balneologie } \\
\text { docent }\end{array}$ & Karlovy Vary (sebevražda) \\
\hline $\begin{array}{l}\text { Winternitz, Rudolf } \\
\text { (21. 3. 1859, Praha - 14. 6. 1942, Terezín) }\end{array}$ & $\begin{array}{l}\text { dermatologie } \\
\text { řádný profesor }\end{array}$ & Terezín \\
\hline
\end{tabular}




\title{
Entfernung/Reinigung/Entjudung: Die Folgen der nazistischen Rassenverfolgung für das Professorenkollegium der Medizinischen Fakultät der Deutschen Universität Prag, 1938-1945
}

\author{
ZUSAMMENFASSUNG
}

Eine Folge der nazistischen Besetzung der böhmischen Länder in den Jahren 1939-1945 waren politisch wie ideologisch motivierte Veränderungen bzw. das erzwungene Karriere-Ende von Wissenschaftlern und Akademikern. Emigration und Exil, rassische Verfolgung oder aktive Beteiligung am Widerstand hatten schicksalhafte (vernichtende) Konsequenzen für die bis dahin multikulturelle und mehrsprachige Zusammensetzung der wissenschaftlichen Gemeinde in den böhmischen Ländern zur Folge. Dies betraf auch unmittelbar die medizinischen Berufe. Am Beispiel ihrer elitären Vertreter, also der Hochschullehrer (Professoren und Dozenten), können die Schicksale eines wichtigen Teils der traditionell deutschsprachigen Wissenschaft und Bildung in den böhmischen Ländern nahegebracht werden. Die vorgelegte Studie kann einerseits zur Forschung beitragen, die auf die Beschreibung und Analyse der Veränderungen des wissenschaftlichen und intellektuellen Personalbestands in den böhmischen Ländern in dem betreffenden Zeitraum abzielt. Andererseits ergänzt sie unsere Kenntnisse, die wir von der Entwicklung der einzelnen Fächer bzw. der wissenschaftlichen Institutionen, konkret der Medizinischen Fakultät der Deutschen Universität Prag besitzen. Quellenmäßig stützt sich unsere Studie auf die Bestände einheimischer und ausländischer Archive.

Deutsche Übersetzung Wolf B. Oerter

Michal V. Šimůnek

Kabinet dějin vědy Ústavu pro soudobé dějiny

Akademie věd České republiky, v. v. i., Praha

simunek@usd.cas.cz 